GPJI 4 (2) (2020)

\title{
HUBUNGAN ANTARA KEKUATAN OTOT TUNGKAI, KELENTUKAN DAN KOORDINASI MATA-KAKI TERHADAP TEKNIK GUNTINGAN ATLET PENCAK SILAT PONDOK PESANTREN MAHASISWA AL-KAUTSAR
}

\begin{abstract}
Addien Nur Habibillah $^{1 \bowtie}$, M. E. Winarno ${ }^{2}$
Universitas Negeri Malang Addienhabib8@gmail.com

\begin{tabular}{l} 
Info Artikel \\
\hline Sejarah Artikel: \\
Diterima: Agustus-2020 \\
Disetujui: Agustus-2020 \\
Dipublikasikan: Bulan-Tahun \\
Kata Kunci: \\
Kekuatan otot tungkai, \\
kelentukan, koordinasi Mata- \\
kaki, guntingan
\end{tabular}

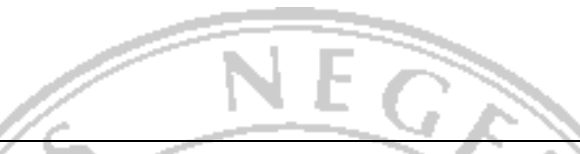

Abstrak

Tujuan penelitian ini adalah untuk mengetahui kecenderungan keterkaitan antara kekuatan otot tungkai, kelentukan dan koordinasi terhadap teknik guntingan atlet pencak silat pondok pesantren mahasiswa al-kautsar. Metode Penelitian ini adalah deskriptif kuantitaf dengan analisis data korelasional, subjek penelitian ini yaitu atlet pencak silat pondok pesantren mahasiswa AlKautsar yang berjumlah 30 atlet. Berdasarkan hasil analisis yang telah dilakukan menunjukkan bahwa; 1) terdapat hubungan antara kekuatan otot tungkai dengan keterampilan teknik guntingan dengan $\mathrm{r}_{\text {hitung }}(0,546)>\mathrm{rt}_{\text {abel }}$ $(0,361), 2)$ terdapat hubungan antara kelentukan dengan teknik guntingan dengan $\left.r_{\text {hitung }}(0,419)>r_{\text {tabel }}(0,361), 3\right)$ terdapat hubungan antara koordinasi dengan keterampilan teknik guntingan diperoleh $r_{\text {hitung }}(0,368)>r_{\text {tabel }}(0,361)$ dan 4) terdapat hubungan yang signifikan antara antara kekuatan otot tungkai, kelentukan dan koordinasi mata-kaki secara bersama-sama terhadap teknik guntingan dengan $\mathrm{R}_{\mathrm{y} \cdot \mathrm{x} 1 \times 2 \times 3}(0,622)>\mathrm{r}_{\text {tabel }}(0,361)$. Kesimpulan dari penelitian ini adalah sebagai berikut" 1) Kekuatan otot tungkai memiliki hubungan yang signifikan dengan teknik guntingan, 2) kelentukan memiliki hubungan yang signifikan dengan teknik guntingan, 3) koordinasi mata-kaki memiliki hubungan yang signifikan dengan teknik guntingan, dan 4) kekuatan otot tungkai, kelentukan, dan koordinasi mata kaki secara bersamasama memiliki hubungan yang signifikan dengan teknik guntingan.
\end{abstract}

\begin{abstract}
The purpose of this study was to determine the tendency of the relationship between leg muscle strength, flexibility and coordination of the cutout technique of martial arts athletes at al-kautsar student boarding school. This research is a quantitative descriptive correlational data analysis. the subject of this study was the martial arts athlete of Al-Kautsar Islamic boarding school students totaling 30 athletes. Based on the results of the analysis that has been done shows that; 1) there is a relationship between leg muscle strength and cutout technique skills with rcount (0.546)> rtable $(0.361), 2)$ there is a relationship between flexibility with cutout techniques with rcount (0.419)> rtable $(0.361), 3)$ there is a relationship between coordination with cutout technique skills obtained $r$ count (0.368)> rtabel (0.361) and 4) there is a significant relationship between leg muscle strength, flexibility and eye-foot coordination together with the cutting technique with Ry.x1 $\times 2 \times 3$ (0.622)> rtabel (0.361)). The conclusions
\end{abstract}


of this study are as follows "1) Leg muscle strength has a significant relationship with cutout technique, 2) flexibility has a significant relationship with cutout technique, 3) eye-foot coordination has a significant relationship with cutout technique, and 4) strength Leg muscles, flexibility, and coordination of the ankles together have a significant relationship with the cutting technique.

(C) 2020 Universitas Negeri Malang

Alamat Korespondensi:

E-mail: pjk.journal@um.ac.id

ISSN: 2614-8293 (Online)

\section{PENDAHULUAN}

Pencak silat ialah seni beladiri asli nusantara yang sudah ada sejak zaman nenek moyang. Pada hakikatnya istilah pencak silat memuat 2 kata, memiliki pengertian keahlian untuk membela diri tanpa memberi perlawanan yang dilakukan oleh seorang diri, kemudian silat berarti kemampuan untuk menyerang pada saat perkelahian terjadi. Jadi pencak silat merupakan keahlian seseorang melakukan teknik bertahan dan menyerang dalam waktu bersamaan yang telah terencana. Haryadi (2003:2) menerangkan bahwa pencak silat memiliki fungsi untuk membeladiri dari segala macam jenis serangan, khususnya berasal dari manusia. Di Indonesia pencak silat berkembang dengan pesat, hal tersebut tergambar dari banyaknya aliran atau jenis pencak silat yang didirikan dengan masing-masing memiliki basis anggota yang besar.

Dalam mengikuti pencak silat kebugaran jasmani yang baik, sebab akan mempengaruhi performa pada saat sedang membela diri ataupun mengikuti pertandingan. Menurut Qur'ani (2016) kebugaran jasmani memiliki hubungan dengan prestasi atlet pencak silat seni tunggal. Hal ini tidak terlepas dari dibutuhkannya kebugaran jasmani dalam melakukan gerak dasar pencak silat. Penggunaan teknik yang dapat digunakan dalam pertandngan dibatasi. Hal ini diatur oleh IPSI selaku induk organisasi pencak silat di Indonesia, peraturan ini dimaksudkan untuk mewujudkan tujuan olahraga yaitu kesenangan dan pertandingan yakni persaudaraan. Selain itu adanya peraturan juga dapat memproteksi atlet dari kemungkinan cedera yang akan terjadi. Teknik dalam pencak silat terdiri dari pasang, langkah, belaan, serangan dan jatuhan (Mulyana, 2014:112). Kemudian (Rahayuni, 2012:9) juga hampir sama dengan sebelumnya dimana teknik dasar pencak silat terdiri dari pasang, langkah, belaan, serangan menggunakan kaki dan tangan hingga teknik jatuhan.

Guntingan termasuk teknik menjatuhkan lawan yang sering digunakan atlet pencak silat dalam kategori tanding. Secara teknis, guntingan dilakukan dengan cara mengapitkan kaki ke pinggang atau bisa juga ke tungkai lawan hingga keseimbangan terganggu lalu terjatuh (Lubis, 2014:32). Lalu Subagyo (2012:39) mengatakan teknik guntingan adalah teknik menjatuhkan lawan yang dilaksanakan dengan menjepitkan kedua tungkai pada tubuh dan tungkai lawan sehingga lawan terjatuh.Teknik guntingan sering digunakan oleh pesilat karena teknik ini praktis, aman, serta mendapat poin yang besar apabila bisa berhasil. Dari hasil wawancara penulis terhadap pelatih pencak silat di Pondok Pesantren Mahasiswa (PPM) Al-Kautsar yakni kepada saudara Galang Hanafian Pratama menuturkan bahwa pelaksanaan teknik guntingan belum menuai hasil yang maksimal. Hal inilah yang mendasari peneliti untuk meneliti teknik guntingan.

Kebugaran adalah kesanggupan tubuh untuk melakukan kegiatan dengan intensitas tinggi tanpa mengalami keletihan berlebih (Mukholid, 2004:3). Setiap orang mempunyai tingkat kebugaran jasmani masing-masing dengan tingkatan beragam dan pastinya tidak sama. Untuk atlet tanding diharuskan memiliki tingkat kebugaran jasmani dengan kategori sangat baik. Kebugaran jasmani yang baik sangat mempengaruhi performa atlet pada saat bertanding (Setiawan, 2013). 
Kekuatan yaitu kapasitas otot untuk menjalankan peregangan terhadap beban dengan maksimal (Widiastuti, 2015:15). Kekuatan dibutuhkan dalam pencak silat dan olahraga lainnya yang terdapat kontak fisik. Selaras dengan itu, Rohman \& Efendi, (2019) menyatakan kekuatan sangat diperlukan dalam pencak silat terutama otot tungkai dan otot perut. Teknik guntingan dalam pelaksanaannya akan didominasi oleh tungkai. Dengan demikian keterampilan teknik guntingan akan dipengaruhi oleh kekuatan otot tungkai.

Kelentukan yaitu kompetensi persendian untuk melaksanakan gerakan pada batas maksimal tanpa mengalami cedera. Dalam Mateas (2017) menyatakan kelentukan pinggang berkontribusi pada keterampilan tendangan T yang mencapai 90,25\%. Kemudian Nusufi' (2017) dalam penelitiannya menyatakan bahwa kelentukan mempunyai signifkansi hubungan terhadap speed tedangan sabit pada pencak silat. Dari kedua penelitian yang dilakukan dapat disimpulkan kelentukan memiliki peran penting dalam keterampilan teknik pencak silat.

Koordinasi merupakan unsur kebugaran jasmani yang penting terhadap prestasi. Menurut Nurrochmah (2016:187) koordinasi yakni keahlian untuk melakukan banyak gerakan diberbagai tingkat kesulitan secara efiesien, cepat serta tepat. Koordinasi dibutuhkan dalam setiap cabang olahraga karena memiliki dampak yang signifikan. Koordinasi dibutuhkan oleh seorang atlet pencak silat (Anggraeni, 2017). Untuk meraih kondisi fisik dengan koordinasi yang baik dapat ditingkatkan melalui latihan terprogram. Keterampilan tendangan sabit dengan guntingan memiliki persamaan dimana kedua keterampilan berfokus pada koordinasi mata-kaki.

Pondok Pesantren Mahasiswa (PPM) Al-Kautsar merupakan pondok pesantren yang dihuni oleh santri yang sedang menempuh kuliah di beberapa perguruan tinggi di Malang. Dalam PPM Al-kautsar terdapat latihan pencak silat yang rutin dilakukan disela-sela kegiatan mengaji. Santri yang mengikuti latihan biasanya sering mengikuti berbagai macam kejuaraan pencak silat, tidak sedikit para santri meraih gelar juara di beberapa kejuaraan seperti di kejuaraan yang baru saja digelar yakni Apel Cup kota Malang. Dengan adanya latihan rutin serta keikut sertaan para santri dalam kejuaraan mendasari peneliti untuk melakukan penelitian di Pondok Pesantren Mahasiswa Al-Kautsar.

Dari ketiga unsur kebugaran di atas, dapat dilihat masing-masing memiliki hubungan terhadap keterampilan dalam pencak silat khususnya teknik guntingan. Hal ini menunujukkan betapa vitalnya faktor unsur kebugaran jasmani dalam melakukan teknik guntingan. Melihat pentingnya kebugaran jasmani dalam olahraga pencak silat, maka hal inilah yang mendasari penulis melaksanakan penelitian dengan judul "Hubungan Kekuatan Otot Tungkai, Kelentukan dan Koordinasi Mata-kaki Terhadap Teknik Guntingan Atlet Pencak Silat Pondok Pesantren Mahasiswa Al-Kautsar".

\section{METODE}

Metode penelitian ini adalah penelitian deskriptif kuantitatif dengan menggunakan analisis data korelasional. Korelasi product moment dari Pearson merupakan Teknik analisis yang digunakan dalam penelitian ini adalah analisis korelasi. Analisis korelasional memiliki tujuan untuk mencari tahu adanya keterkaitan antara variabel satu dengan variabel lainnya. Teknik analisis ini membutuhkan minimal 2 variabel atau lebih untuk bisa dikorelasikan. Pada penelitian ini terdapat 4 variabel yang nantinya akan dicari nilai korelasi dari setiap variabel bebas dengan variabel terikat dan secara bersamaan. Jika dijabarkan menggunakan gambar akan seperti di bawah ini: 


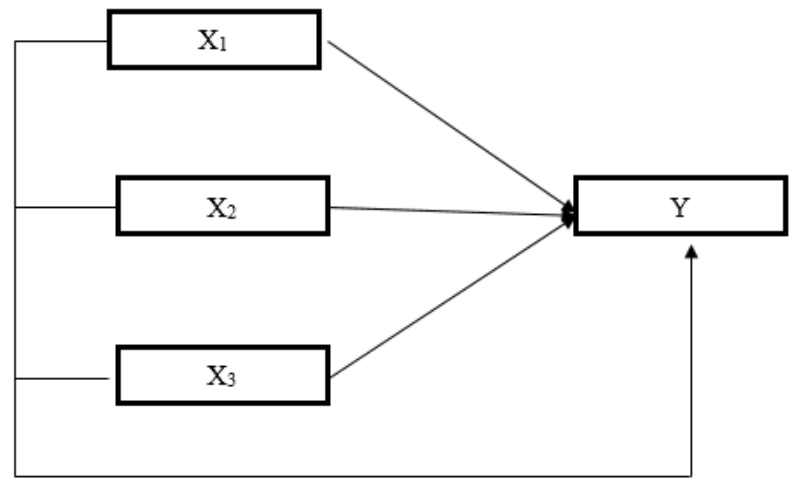

Gambar 1 Rancangan Penelitian Korelasional

Subjek dari penelitian ini menggunakan populasi dari santri Pondok Pesantren Mahasiswa (PPM) Al-Kautsar yang mengikuti latihan pencak silat sebanyak 50 santri. Kemudian dilakukan pengambilan sampel dengan metode purposive sampling yakni terdapat pertimbangan atas dipilihnya subjek tersebut. Pertimbangan tersebut meliputi peserta yang mengikuti latihan dibedakan antara lakilaki dan perempuan sehingga peneliti mengambil yang peserta yang laki-laki mengikuti norma yang ada di Pondok Pesantren. Kemudian peserta harus sudah diajarkan teknik guntingan dan dinilai bisa melakukannya sehingga didapatkan 30 peserta laki-laki.

Instrumen penelitian yang dipakai di penelitian ini sebagai berikut: 1) leg dynamometer yang digunakan guna mengukur variabel bebas kekuatan otot tungkai, 2) sit and reach yang digunakan guna mengetes variabel bebas kelentukan, 3) skipping rope yang digunakan untuk mengukur variabel bebas koordinasi mata-kaki, 4) tes guntingan yang dilakukan ke arah teman sebaya yang berada dalam sikap kuda-kuda dan pasang digunakan untuk mengukur variabel terikat keterampilan teknik guntingan.

Analisis data yang pertama adalah uji prasyarat yakni uji normalitas serta uji linieritas. Sebelum itu, data dirubah ke bentuk Tskor untuk menyamakan data yang akan dianalisis. Selanjutnya melakukan uji hipotesis dengan mencari persamaan regresi $(\hat{Y})$ menggunakan program aplikasi SPSS versi 25. Lalu menghitung korelasi sederhana antara variabel bebas dengan variabel terikat menggunakan analisis korelasi product moment dari pearson menggunakan aplikasi SPSS versi 25. Kemudian melkukan analisis regresi dimana di dalamnya terdapat uji korelasi ganda, uji regresi ganda serta menganalisis sumbangan efektif (SE) dan sumbangan relatif (SR).

\section{HASIL}

Pada deskripsi data ini membahas data angka standar yang akan diubah ke Tskor karena data setiap variabel memiliki satuan yang berbeda. Di bawah ini pada tabel 1 disajikan hasil analisis setiap variabel yang diteliti,

Tabel 1 Deskripsi Data Masing-Masing Variabel

\begin{tabular}{cccccc}
\hline Variabel & $\sum$ & Skor min & Skor max & Mean & Standar Deviasi \\
\hline $\mathrm{X}_{1}$ & 3523,5 & 91 & 138,5 & 117,45 & 11,93 \\
$\mathrm{X}_{2}$ & 553 & 5 & 30 & 18,43 & 6,32 \\
$\mathrm{X}_{3}$ & 3825 & 66 & 200 & 127,5 & 22,14 \\
$\mathrm{Y}$ & 369 & 8 & 15 & 12,3 & 1,51 \\
\hline
\end{tabular}


Berdasarkan paparan tabel 1 diketahui kekuatan otot tungkai diperoleh $\sum$ sebesar 3523,5, dengan skor minimal 91, skor maksimal 135, mean seejumlah 117,45, standar deviasi sebanyak 11,93. Untuk kelentukan diperoleh $\sum$ sebesar 553, skor minimal 5, skor maksimal 30, mean sejumlah 18,43, standar deviasi sebanyak 6,32. Untuk koordinasi mata-kaki diperoleh $\sum$ sebesar 3825, skor minimal 66, skor maksimal 200, mean sebesar 127,5, standar deviasi sebesar 22,14. Untuk teknik guntingan diperoleh $\sum$ sebesar 369, skor minimal 8, skor maksimal 15 mean sebesar 12,3, standar deviasi sebesar 1,51.data-data tersebut masih harus dirubah menjadi Tskor menggunakan Microsoft excel.

Tabel 2 Hasil Uji Normalitas

\begin{tabular}{|c|c|c|c|}
\hline \multirow[b]{2}{*}{ Variabel } & \multicolumn{3}{|c|}{ Liliefors } \\
\hline & $\begin{array}{c}\text { Hasil analisis } \\
\left(\mathrm{L}_{\max }\right)\end{array}$ & $\begin{array}{c}\text { Nilai tabel L } \\
(0,05)\end{array}$ & Keterangan \\
\hline Kekuatan otot tungkai & 0,082 & 0,161 & $\mathrm{~L}_{\text {hit }}<\mathrm{L}_{\text {tab }}$ (normal) \\
\hline Kelentukan & 0,098 & 0,161 & $\mathrm{~L}_{\text {hit }}<\mathrm{L}_{\mathrm{tab}}$ (normal) \\
\hline Koordinasi mata-kaki & 0,150 & 0,161 & $\mathrm{~L}_{\text {hit }}<\mathrm{L}_{\text {tab }}($ normal $)$ \\
\hline Keterampilan guntingan & 0,155 & 0,161 & $\mathrm{~L}_{\text {hit }}<\mathrm{L}_{\mathrm{tab}}$ (normal) \\
\hline
\end{tabular}

Dari hasil uji normalitas dalam tabel di atas diketahui jika nilai signifikansi kekuatan otot tungkai sebesar 0,082, hasil analisis data $0,082<0,161$, maka data variabel kekuatan otot tungkai bersifat normal, signifikasi kelentukan sebesar 0,098, hasil analisis data $0,105<0,098$, maka variabel kelentukan berdistribusi normal, signifikasi koordinasi sebesar 0,150, hasil analisis data $0,150<0,161$, maka variabel koordinasi berdistribusi normal, signifikasi keterampilan guntingan sebesar 0,155 dan $\alpha=0,05$, hasil analisis data $0,155<0,161$, maka yariabel keterampilan guntingan berdistribusi normal.

Tabel 3 Hasil Uji Linieritas

\begin{tabular}{|c|c|c|c|c|c|c|}
\hline \multirow{2}{*}{ No } & \multirow{2}{*}{ Variabel } & \multirow{2}{*}{$\mathrm{A}$} & \multirow{2}{*}{\multicolumn{2}{|c|}{8}} & Hasil Analisis & 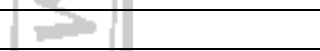 \\
\hline & & & & & $\mathbf{F}_{\text {tabel }}$ & Keterangan \\
\hline 1 & $\mathrm{X}_{1} \mathrm{Y}$ & & 2,673 & & 8,63 & $\mathrm{~F}_{\text {hitung }}<\mathrm{F}_{\text {tabel }}$ (linier) \\
\hline 2 & $\mathrm{X}_{2} \mathrm{Y}$ & & 0,397 & & 2,60 & $\mathrm{~F}_{\text {hitung }}<\mathrm{F}_{\text {tabel }}($ linier $)$ \\
\hline 3 & $\mathrm{X}_{3} \mathrm{Y}$ & & 3,181 & & 4,53 & $\mathrm{~F}_{\text {hitung }}<\mathrm{F}_{\text {abel }}$ (linier) \\
\hline
\end{tabular}

Dari hasil uji linieritas pada tabel 3 di atas dapat diketăhui bahwa nilai $\mathrm{F}_{\text {hitung }} \mathrm{X}_{1} \mathrm{Y}$ sebesar 2,673 dan $\mathrm{F}_{\text {tabel }}=8,63$ hasil analisis data $\mathrm{F}_{\text {hitung }}<\mathrm{F}_{\text {tabel }}$ maka terdapat hubungan yang linier antara variabel kekuatan otot tungkai dengan variabel keterampilan guntingan, nilai $F_{\text {hitung }} \mathrm{X}_{2} \mathrm{Y}$ sebesar 0,397 dan $\mathrm{F}_{\text {tabel }}=2.60$ hasil analisis data $\mathrm{F}_{\text {hitung }}<\mathrm{F}_{\text {tabel }}$ maka terdapat hubungan yang linier antara variabel kelentukan dengan variabel keterampilan guntingan, nilai $\mathrm{F}_{\text {hitung }} \mathrm{X}_{3} \mathrm{Y}$ sebesar 3,181 dan $\mathrm{F}_{\text {tabel }}=4,53$ hasil analisis data $F_{\text {hitung }}<F_{\text {tabel }}$ maka terdapat hubungan yang linier antara variabel koordinasi dengan variabel keterampilan guntingan.

Tabel 4 Persiapan Mencari Persamaan Regresi $\hat{Y}$

\begin{tabular}{lc}
\hline & Unstandardized coefficients \\
\cline { 2 - 2 } \multicolumn{1}{c}{ Model } & B \\
\hline Constant $\left(\mathrm{b}_{0}\right)$ & 9,985 \\
Kekuatan otot tungkai $\left(\mathrm{b}_{1}\right)$ & 0,447 \\
Kelentukan $\left(\mathrm{b}_{2}\right)$ & 0,243 \\
Koordinasi mata-kaki $\left(\mathrm{b}_{3}\right)$ & 0,110 \\
\hline Dependent variabel: tekik
\end{tabular}

Dependent variabel: teknik guntingan

Berdasarkan hasil perhitungan menggunakan program SPSS versi 25 dengan data pada tabel 4 , diperoleh nilai $b_{0}=9,985$, koefisien arah $b_{1}=0,447$, koefisien arah $b_{2}=0,243$, koefisien arah $b_{3}=$ 
0,110 dengan hasil tersebut maka regresi keterampilan guntingan $(\mathrm{Y})$ atas kekuatan otot tungkai (X1), kelentukan (X2), dan koordinasi mata-kaki (X3) adalah $\hat{Y}=9,985+0,447 \mathrm{X}_{1}+0,243 \mathrm{X}_{2}+0,110 \mathrm{X}_{3}$.

Tabel 5 Hasil Perhitungan Variabel Bebas yang dikorelasikan dengan Variabel Terikat

\begin{tabular}{|c|c|c|c|c|}
\hline No & Variabel & $\mathbf{r}_{\text {hitung }}$ & $\mathbf{r}_{\text {tabel }}$ & Keterangan \\
\hline 1 & $\begin{array}{l}\text { Kekuatan otot tungkai dengan } \\
\text { keterampilan guntingan }\end{array}$ & 0,546 & 0,361 & $\begin{array}{l}r_{\text {hitung }}>\text { rtabel terdapat } \\
\text { hubungan }\end{array}$ \\
\hline 2 & $\begin{array}{l}\text { Kelentukan dengan keterampilan } \\
\text { guntingan }\end{array}$ & 0,419 & 0,361 & $\begin{array}{l}r_{\text {hitung }}>r_{\text {tabel }} \text { terdapat } \\
\text { hubungan }\end{array}$ \\
\hline 3 & $\begin{array}{l}\text { Koordinasi mata-kaki dengan } \\
\text { keterampilan guntingan }\end{array}$ & 0,368 & 0,361 & $\begin{array}{l}r_{\text {hitung }}>r_{\text {tabel }} \text { terdapat } \\
\text { hubungan }\end{array}$ \\
\hline
\end{tabular}

Hasil analisis korelasi product moment antara variabel kekuatan otot tungkai $\left(\mathrm{X}_{1}\right)$ dengan teknik guntingan $(\mathrm{Y})$ diperoleh hasil $\mathrm{r}_{\text {hitung }}$ sebesar 0,546 , variabel kelentukan $\left(\mathrm{X}_{2}\right)$ dengan keterampilan guntingan $(\mathrm{Y})$ diperoleh hasil $\mathrm{r}_{\text {hitung }}$ sebesar 0,419 variabel koordinasi dengan keterampilan guntingan (Y) diperoleh hasil $\mathrm{r}_{\text {hitung }}$ sebesar 0,368 dan $\mathrm{r}$ tabel $\mathrm{n}=30$ adalah 0,361 . Maka dapat dinyatakan variabel kekuatan otot tungkai $\left(\mathrm{X}_{1}\right)$ dengan keterampilan guntingan $(\mathrm{Y})$, variabel kelentukan $\left(\mathrm{X}_{2}\right)$ dengan keterampilan guntingan $(\mathrm{Y})$, variabel koordinasi $\left(\mathrm{X}_{3}\right)$ dengan keterampilan guntingan $(\mathrm{Y})$ dinyatakan terdapat berhubungan

Tabel 6 Rangkuman Hasil Perhitungan Koefisien Korelasi Variabel Bebas dengan Variabel Terikat

\begin{tabular}{|c|c|c|c|c|c|c|c|c|c|}
\hline \multirow{2}{*}{$\begin{array}{c}\text { Mod } \\
\text { el }\end{array}$} & \multirow[b]{2}{*}{$\mathrm{R}$} & \multirow{2}{*}{$\begin{array}{c}\mathrm{R} \\
\text { Square }\end{array}$} & \multirow{2}{*}{$\begin{array}{l}\text { Adjusted } \\
\text { R Square }\end{array}$} & \multirow{2}{*}{$\begin{array}{c}\text { Std. Error } \\
\text { of the } \\
\text { Estimate }\end{array}$} & \multicolumn{5}{|c|}{ Change Statistics } \\
\hline & & & & & $\begin{array}{c}\text { R Square } \\
\text { Change }\end{array}$ & $\begin{array}{c}\mathrm{F} \\
\text { Change }\end{array}$ & df1 & df2 & Sig. F Change \\
\hline 1 & $.622^{\mathrm{a}}$ & .386 & .315 & 8.27350 & .386 & 5.455 & 3 & 26 & .005 \\
\hline
\end{tabular}

Dari data di atas didapatkan hasil koefisien korelas sebesar 0,622 dengan rtabel untuk $n=30$ adalah 0,361 . Maka semua variabel bebas secara bersamaan memiliki hubungan yang signifikan dengan variabel terikat.

Tabel 7 Hasil Perhitungan Statistik Regresi

\begin{tabular}{cc}
\hline & \\
\hline Multiple R & $0,622^{\mathrm{a}}$ \\
R squere & 0,386 \\
Adjusted R squere & 0,315 \\
Standard error & 8,27350 \\
Observations & 30 \\
\hline
\end{tabular}

Berdasarkan hasil perhitungan statistik regresi tabel 7 dapat diketahui adjusted $R$ squere atau regresi ganda dari semua variabel bebas memberikan pengaruh ke variabel terikat keterampilan guntingan (Y) sebesar 0,386 atau 38,6\% dan sisanya dipengaruhi oleh variabel lain.

Tabel 8 Rangkuman Hasil Analisis Regresi

\begin{tabular}{llccccc}
\hline & & Sum of & & & \\
& Model & squere & Df & Mean squere & F & Sig \\
\hline 1 & Regression & 1120,277 & 3 & 373.426 & 5.455 & $.005^{\text {b }}$ \\
& Residual & 1779,723 & 26 & 68.451 & & \\
& Total & 2900.000 & 29 & & & \\
\hline
\end{tabular}


Berdasarkan hasil pada tabel 8 diketahui bahwa signifikasi sebesar $0,005<0,05$ maka dengan bersamaan variabel kekuatan otot tungkai $\left(\mathrm{X}_{1}\right)$, kelentukan $\left(\mathrm{X}_{2}\right)$, dan koordinasi mata-kaki $\left(\mathrm{X}_{3}\right)$ berhubungan yang signifikan terhadap variabel keterampilan guntingan $(\mathrm{Y})$.

Table 9 Persiapan Untuk Menghitung Sumbangan Efektif dan Sumbangan Relatif

\begin{tabular}{ccc}
\hline Variabel & Sumbangan Efektif (SE) & Sumbangan Relatif (SR) \\
\hline Kekuatan otot tungkai & $24,40 \%$ & $63,16 \%$ \\
Kelentukan & $10,18 \%$ & $26,36 \%$ \\
koordinasi & $4,04 \%$ & $10,48 \%$ \\
\hline
\end{tabular}

Berdasarkan tabel 9 dapat dilakukan perhitungan dan diperoleh hasil sumbangan efektif yang diberikan dari seluruh variabel bebas secara bersamaan adalah 38,63\% lalu secara terpisah sumbangan yang diberikan oleh variabel $\mathrm{X}_{1}$ adalah sebesar $24,40 \%$ sedangkan $\mathrm{X}_{2}$ sebesar $10,18 \%$ dan $\mathrm{X}_{3}$ sebesar $4,04 \%$. Sumbangan relatif yang dihasilkan oleh variabel $X_{1}$ adalah sebesar $63,16 \%, X_{2}$ sebesar $26,36 \%$ dan $\mathrm{X}_{3}$ sebesar $10,48 \%$.

Dari pengujian hipotesis yang sudah dilakukan didapatkan hasil sebagai berikut: 1) koefisien korelasi $\mathrm{r}$ dari variabel bebas kekuatan otot tungkai $\left(\mathrm{X}_{1}\right)$ terhadap variabel terikat keterampilan teknik guntingan $(\mathrm{Y})$ didapatkan hasil sebesar $0,546>$ dari ${ }_{\text {tabel }}$ sebesar $\left.0,361,2\right)$ koefisien korelasi $r$ dari variabel bebas kelentukan $\left(\mathrm{X}_{2}\right)$ terhadap variabel terikat teknik guntingan $(\mathrm{Y})$ didapatkan hasil sebesar $0,419>$ dari $\mathrm{r}_{\text {tabel }}$ sebesar $\left.0,361,3\right)$ koefisien korelasi $\mathrm{r}$ dari variabel bebas koordinasi mata-kaki $\left(\mathrm{X}_{3}\right)$ terhadap variabel terikat keterampilan teknik guntingan $(\mathrm{Y})$ didapatkan hasil sebesar $0,368>$ dari $\mathrm{r}_{\text {tabel }}$ sebesar $0,368,4)$ koefisien korelasi $\mathrm{r}$ dari variabel bebas kekuatan otot tungkai, kelentukan, dan koordinasi mata-kaki dengan variabel terikat teknik guntingan didapatkan hasil sebesar $0,622>$ dari $\mathrm{r}_{\text {tabel }}$ sebesar 0,361 . Dengan demikian setiap masing-masing variabel bebas dan secara bersamaan yang dikorelasikan dengan variabel terikat memiliki hubungan signifikan.

\section{PEMBAHASAN}

Hubungan Antara Kekuatan Otot Tungkai dengan Teknik Guntingan Atlet Pencak Silat Pondok Pesantren Mahasiswa Al-Kautsar

Hasil analisis korelasi signifikasi pada penelitian ini dapat dinyatakan bahwa kekuatan otot tungkai termasuk faktor kesuksesan dalam melakukan teknik guntingan atlet pencak silat. Hal tersebut diperkuat oleh hasil penelitian sebelumnya mengenai kekuatan otot tungkai yang dikorelasikan dengan teknik pencak silat khususnya dilakukan oleh kaki yang dilakukan oleh Arfan (2011) bahwa kecepatan tendangan sabit sangat berhungan dengan kekuatan otot tungkai. Ada hubungan yang bermakna antara Kekuatan otot tungkai terhadap kecepatan tendangan sabit. (Harianja, 2015). Prasetyo, J., Jubaedi, A., \& Suranto, (2017) dalam penelitiannya menyebutkan kekuatan otot tungkai berhubungan signifikan dengan keterampilan tendangan sabit.

\section{Hubungan Antara Kelentukan dengan Teknik Guntingan Atlet Pencak Silat Pondok Pesantren Mahasiswa Al-Kautsar}

Hasil analisis korelasi signifikasi dalam penelitian ini kelentukan merupakan salah satu faktor penunjang kemampuan teknik guntingan. Hal tersebut telah diperkuat oleh Afiana, A., Husin, S., \& Hermawan (2014) bahwa kelentukan menjadi faktor keberhasilan melakukan keterampilan tendangan sabit. Terdapat hubungan yang bermakna antara unsur kebugaran jasmani kelentukan dengan keterampilan tendangan samping pada olahraga pencak silat (Vera, 2012). Selaras dengan itu Mustafa 
(2016) dalam penelitiannya menyebutkan kelentukan mempunyai hubungan signifikan dengan kecepatan saat melakukan tendangan sabit.

\section{Hubungan Antara Koordinasi dengan Teknik Guntingan Atlet Pencak Silat Pondok Pesantren Mahasiswa Al-Kautsar}

Hasil analisis korelasi signifikasi dalam penelitian ini koordinasi mata-kaki termasuk faktor penunjang keberhasilan melakukan teknik guntingan. Hal ini didukung oleh Wardhana (2011) dalam penelitiannya menyatakan koordinasi memiliki hubungan yang signifikan dengan keterampilan tendangan melingkar. Koordinasi memiliki signifikansi hubungan terhadap keahlian bermain pencak silat (Mistar, 2016). Subekti (2014) dalam penelitiannya menyebutkan adanya hubungan signifikansi untuk koordinasi mata-kaki terhadap keterampilan tendangan $C$.

\section{Hubungan Antara Kekuatan Otot Tungkai, Kelentukan dan Koordinasi Mata-kaki dengan Teknik Guntingan Atlet Pencak Silat Pondok Pesantren Mahasiswa Al-Kautsar}

Hasil korelasi signifikasi antara kekuatan otot tungkai, kelentukan, dan koordinasi mata-kaki memiliki hubungan terhadap keterampilan teknik guntingan dalam pencak silat. Hasil penelitian ini belum bisa diperkuat dengan hasil penelitian terdahulu yang meneliti tentang unsur kebugaran jasmani dengan keterampilan teknik guntingan. Peneliti berharap agar hasil penelitian mengenai korelasi beberapa unsur kebugaran jasmani dengan keterampilan teknik guntingan dapat dijadikan rujukan penelitian lainnya mengenai teknik guntingan.

\section{KESIMPULAN}

Kesimpulan dari penelitian ini ialah: 1) Kekuatan otot tungkai mempunyai hubungan yang signifikan terhadap teknik guntingan atlet pencak silat Pondok Pesantren Mahasiswa Al-Kautsar, 2) Kelentukan memiliki hubungan yang signifikan terhadap teknik guntingan atlet pencak silat Pondok Pesantren Mahasiswa Al-Kautsar, 3) Koordinasi mata-kaki memiliki hubungan yang signifikan terhadap teknik guntingan atlet pencak silat Pondok Pesantren Mahasiswa Al-Kautsar, 4) Terdapat hubungan yang signifikan antara kekuatan otot tungkai, kelentukan, dan koordinasi mata-kaki terhadap teknik guntingan atlet pencak silat Pondok Pesantren Mahasiswa Al-Kautsar.

\section{DAFTAR PUSTAKA}

Afiana, A., Husin, S., \& Hermawan, R. 2014. Kontribusi Panjang, Kelentukan, Daya Ledak Otot Tungkai Terhadap Tendangan Sabit Pencak Silat. JUPE (Jurnal Penjaskesrek), 2(4), 1-9.

Anggraeni, J. L. 2017. Profil Kondisi Fisik UKM Pencak Silat UNESA (Putra). Jurnal Prestasi Olahraga, 1(1), 1-10.

Arfan, M. 2011. Hubungan Antara Kekuatan Tungkai dan Kelentukan Tungkai dengan Kecepatan Tendangan Sabit pada Olahraga Pencaksilat Siswa SMK Negeri 2 Belopa. Jurnal Competitor, $3(2), 1-12$.

Harianja, D. H. 2015. Kontribusi Kekuatan Otot Tungkai terhadap Kecepatan Tendangan Sabit pada Siswa Ekstrakurikuler Pencak Silat SMA Negeri 2 Tambang Kabupaten Kampar. Jurnal 
Online Mahasiswa Fakultas Keguruan dan Ilmu Pendidikan Universitas Riau, 2(2), 1-11.

Haryadi, R. K. S. 2003. Teknik Dasar Pencak Silat Tanding. Jakarta: Dian Rakyat.

Lubis, J. 2014. Pencak Silat: Panduan Praktis Edisi Ke 2. Jakarta: Rajagrafindo Persada.

Mateas, J. D. 2017. Kontribusi Kelenturan dan Kelentukan Pinggang terhadap Keterampilan Tendangan T pada Ekstrakurikuler Pencak Silat SMAN 1 Seluma. Tesis tidak diterbitkan. Bengkulu: FKIP UNIB.

Mistar, J. 2016. Hubungan Konsentrasi, Kekuatan Otot Tungkai, Kecepatan Reaksi dan Koordinasi Mata-Kaki dengan Kemampuan Bermain Pencak Silat. Jurnal Sport Pedagogy: Program Pascasarjana Unsyiah, 6(1), 1-3.

Mukholid, A. 2004. Pendidikan Jasmani. Surakarta: Yudistira.

Mulyana. 2014. Pendidikan Pencak Silat. Bandung: Remaja Rosdakarya.

Mustafa, M. A. 2016. Kontribusi Keseimbangan, Kelentukan Panggul dan Daya Ledak Otot Tungkai terhadap Hasil Tendangan Sabit Cabang Olahraga Pencak Silat.Disertasi tidak diterbitkan. Bandung: FPOK UPI.

Nurrochmah, S. 2016. Tes dan Pengukuran dalam Pendidikan Jasmani \& Olahraga. Malang: UM PRESS.

Nusufi, M. 2015. Hubungan Kelentukan dengan Kemampuan Kecepatan Tendangan Sabit Pada Atlet Pencak Silat Binaan Dispora Aceh (PPLP dan Diklat) Tahun 2015. Jurnal Ilmu Keolahragaan, 14(1), 35-46.

Prasetyo, J., Jubaedi, A., \& Suranto, S. 2017. Kontribusi Kekuatan Otot Tungkai, Keseimbangan dan Kecepatan terhadap Kemampuan Tendangan Sabit. JUPE (Jurnal Penjaskesrek), 5(2), 1-8.

Qur'ani, L. I. 2016. Hubungan Tingkat Kebugaran Jasmani terhadap Prestasi Pencak Silat Jurus Seni Kategori Tunggal pada Kejuaraan Pencak Silat Jurus Seni Kategori Tunggal Pada Kejuaraan O2SN SMP se-Kota Semarang. Skripsi tidak diterbitkan. Semarang: FIK UNNES.

Rahayuni, K. 2012. Pencak Silat PKO. Malang: Universitas Negeri Malang.

Rohman, U. 2019. Profil Kondisi Fisik Atlet PPLP Pencak Silat Jawa Timur. Journal Physical Education, Health and Recreation, 3(2), 112-121.

Setiawan, D. 2013. Kondisi Fisik Pemain Sepakbola Klub Asyabab di Kabupaten Sidoarjo. Jurnal Kesehatan Olahraga, 1(1), 1-5.

Subagyo. 2012. Pencak Silat Untuk Mahasiswa dan Umum. Surabaya: Unesa University Press.

Subekti, N. 2014. Kemampuan Tendangan sabit Mahasiswa Pembinaan Prestasi Pencak Silat UNS Surakarta Ditinjau dari Koordinasi Mata-Kaki Kecepatan Rasio Panjang Tungkai dan Tinggi Badan . Disertasi tidak diterbitkan. Surakarta: Fakultas Keolahragaan UNS.

Vera, D. 2012. Kontribusi Kelentukan dan Power Otot Tungkai terhadap Tendangan Samping Atlet Pencak Silat UKO Universitas Negeri Padang. Disertasi tidak diterbitkan. Padang; FIK UNP. 
Wardhana, A. 2011. Hubungan Keseimbangan dan Koordinasi Mata-Kaki dengan Kemampuan Tendangan Melingkar Pada Perguruan Pencak Silat PATBANBU Kota Bukittinggi. Diesertasi tidak diterbitkan. Padang: FIK UNP.

Widiastuti. 2015. Tes dan Pengukuran Olahraga. Jakarta: Rajagrafindo Persada.

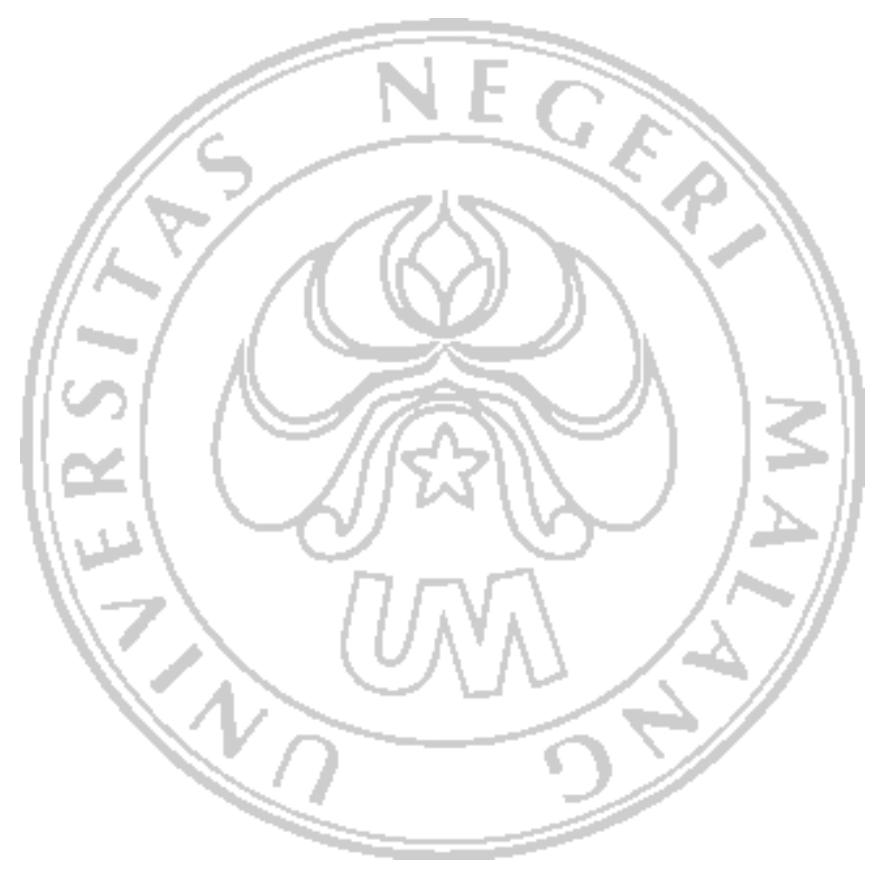

